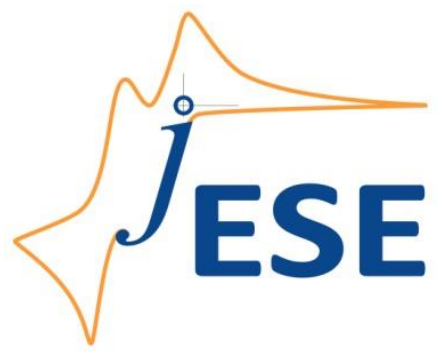

Open Access : : ISSN 1847-9286

www.jESE-online.org

Original scientific paper

\title{
Electrochemical treatment of leachates from sanitary landfills
}

\author{
ANNABEL FERNANDES ${ }^{\bowtie}$, EDITE CATALÃO, LURDES CIRÍACO, MARIA J PACHECO and \\ ANA LOPES \\ UMTP and Department of Chemistry, University of Beira Interior, 6201-001 Covilhã, Portugal \\ ${ }^{\square}$ Corresponding Author: E-mail: E-mail:annabelf@ubi.pt; Tel.: +351275329259; Fax: +351275319730 \\ Received: December 19, 2012; Published: June 12, 2013
}

\begin{abstract}
The electrochemical treatment of leachate samples from a Portuguese intermunicipal sanitary landfill was carried out using anodic oxidation. The treatment was performed in a pilot plant that possesses an electrochemical cell, with boron-doped diamond electrodes, working in batch mode with recirculation. The influence of the applied current density and the flow rate on the performance of the electrochemical oxidation was investigated. Current density was decreased by steps, during the degradation, in order to study this effect on the efficiency of the process. For the assays run at equal flow rate and initial current intensity, chemical oxygen demand (COD) removal seems to depend mainly on the charge passed and the variation of the current density during the anodic oxidation process can reduce the energetic costs. An increase in the recirculation flow rate leads to an increase in the organic load removal rate and a consequent decrease in the energetic costs, but it decreases the nitrogen removal rate. Also, the bias between dissolved organic carbon and COD removals increases with flow rate, indicating that an increase in recirculation flow rate decreases the mineralization index.
\end{abstract}

\section{Keywords}

Landfill leachate treatment; BDD; anodic oxidation.

\section{Introduction}

Leachate generation is an inevitable consequence of the deposition of solid wastes in sanitary landfills. It is the result of rainwater percolation through wastes, that extracts and brings with it several pollutant materials dissolved and in suspension [1]. Sanitary landfill leachate composition is very complex and depends mainly on the type of solid wastes that are deposited, the climatic conditions and the age of the sanitary landfill [2]. Inadequate leachate management involves considerable risks, particularly contamination of water resources, at the surface and groundwater, and soils [1].

A common treatment for sanitary landfill leachates comprises biological reactors with nitrification/denitrification steps, followed by membrane technologies. However, due to variability 
in the quality and quantity of leachate throughout the life span of the treatment plant, these conventional treatments become ineffective. Thus, it is necessary to implement technologies that can be adjusted to the in situ needs [3]. Electrochemical technologies have shown high efficiency in the elimination of persistent pollutants and several studies have described the application of electrochemical methods in wastewater treatment [4-10].

A promising electrochemical method that can be used in wastewater treatment is the anodic oxidation. Despite several different materials are being used as anodes in the oxidation of persistent pollutants, the best results are obtained with boron-doped diamond (BDD) anodes, due to their unique chemical, electrochemical and structural stabilities that allow their use at high potentials, where most organic pollutants can be oxidized [11-13]. There are already several reports describing the application of electrochemical oxidation with BDD anodes for the treatment of landfill leachates [14-24].

Cabeza and co-workers [14,15] reported the application of electrochemical oxidation process, using a BDD anode, to treat raw leachates and biologically and physicochemically pre-treated leachates from a municipal landfill site. Experimental results showed very high chemical oxygen demand (COD) and ammonia removals, although ammonia removal was slower than that of COD. They also observed that when additional chloride ions were provided, the treatment efficiency increased. Anglada and co-workers $[17,20,21]$ also studied the effect of the applied current density and of the initial concentration of chloride ions, as well as the influence of other operating conditions, such as treatment time and initial $\mathrm{pH}$, in the electrochemical oxidation of landfill leachates, using a BDD anode. They have shown that when high current densities are applied, a change in the mechanism of the organic matter oxidation occurs and that organic matter and ammonia oxidation are highly influenced by the applied current density [17]. Also, they have reported that the concentration of chloride has an effect on the oxidation of ammonia and that chloride ions compete with organic matter to be oxidized at the anode. It was found that some chlorinated organic compounds are formed as a result of organic matter oxidation and their concentration increase continuously with treatment time [21]. Acidic conditions were found to favour the formation of haloacetonitriles and haloketons. A kinetic modelling of the electrochemical removal of ammonium and COD from landfill leachates was proposed in literature [23-24]. Authors found that the use of BDD anodes promotes the generation of hydroxyl radicals, while the high content of chloride induces the simultaneous formation of free chlorine, responsible for the ammonium indirect oxidation and for the formation of undesirable products such as chloramines, chlorate and perchlorate. Chlorine evolution is enhanced at lower COD concentrations. During this process, ammonium removal leads to the formation of nitrogen gas and nitrate as the main oxidation products.

In this work, the influence of the raw leachate dilution on the electrochemical degradation of a biologically pre-treated leachate from a sanitary landfill, using a BDD anode, was assessed and it has shown that mineralization of the organic matter improves with the dilution of the leachate [22]. However, an increase in the dilution greatly increases the energy consumption.

The aim of this work was to study the influence of flow rate and applied current density, carried out with multiple step electro-oxidation, on the performance of the electrochemical oxidation of raw leachate from a sanitary landfill. The energy consumption in the different experimental conditions tested was also assessed. 


\section{Experimental}

The leachate samples used in this study were collected at a Portuguese intermunicipal sanitary landfill site, in the equalization tank, before any kind of treatment. Samples characterization is presented in Table 1.

Experiments were conducted in a semi-pilot plant operating in batch mode with recirculation, at room temperature and natural $\mathrm{pH}$, without adding background electrolyte. A BDD DiaCell 100 electrochemical cell, with an electrode area of $70 \mathrm{~cm}^{2}$, and a DiaCell-PS1500 power supply, with automatic polarity reversal, were used. In all assays, automatic polarity reversal occurred every minute. Different current densities, between 50 and $200 \mathrm{~mA} \mathrm{~cm}$, and different flow rates, between 100 and $950 \mathrm{~L} \mathrm{~h}^{-1}$, were tested in sample volumes of 5, 10 or $15 \mathrm{~L}$. During the degradation process, current density was kept constant or decreased by steps, in order to study this effect on the efficiency of the process. Potential differences between anode and cathode were registered throughout the experiments in order to determine energetic consumptions. All assays were performed in duplicate.

Degradation tests were followed by chemical oxygen demand (COD), dissolved organic carbon (DOC), total nitrogen (TN), total Kjeldahl nitrogen (TKN) and ammonia nitrogen (AN).

Table 1. Physicochemical characteristics of the raw leachate.

\begin{tabular}{|c|c|}
\hline Parameter & Medium value $\pm S D^{*}$ \\
\hline COD, $\mathrm{g} \mathrm{L}^{-1}$ & $8.9 \pm 0.8$ \\
\hline $\mathrm{BOD}_{5}, \mathrm{~g} \mathrm{~L}^{-1 * *}$ & $1.3 \pm 0.3$ \\
\hline $\mathrm{BOD}_{5} / \mathrm{COD}$ & $0.15 \pm 0.05$ \\
\hline $\mathrm{DOC}, \mathrm{g} \mathrm{L}^{-1}$ & $3.5 \pm 0.4$ \\
\hline $\mathrm{TN}, \mathrm{g} \mathrm{L}^{-1}$ & $2.8 \pm 0.2$ \\
\hline TKN, $g^{-1}$ & $2.4 \pm 0.2$ \\
\hline AN, $\mathrm{g} \mathrm{L}^{-1}$ & $2.2 \pm 0.3$ \\
\hline$c_{\text {Chloride }} / \mathrm{g} \mathrm{L}^{-1}$ & $4.5 \pm 0.3$ \\
\hline CSuspended Solids / g L ${ }^{-1}$ & $0.7 \pm 0.1$ \\
\hline$C_{\text {Dissolved Solids } / \mathrm{g} \mathrm{L}^{-1}}$ & $16.6 \pm 0.1$ \\
\hline $\mathrm{pH}$ & $8.3 \pm 0.2$ \\
\hline Conductivity, $\mathrm{mS} \mathrm{cm}^{-1}$ & $29.1 \pm 1.0$ \\
\hline
\end{tabular}

COD determinations were made using the closed reflux and titrimetric method [25]. DOC and TN were measured in a Shimadzu TOC-V CSH analyser. Before DOC and TN determinations, samples were filtrated through $1.2 \mu \mathrm{m}$ glass microfiber filters. TKN and AN were determined according to standard procedures using a Kjeldatherm block-digestion-system and a Vapodest 20s distillation system, both from Gerhardt [25].

\section{Results and Discussion}

The effect of the applied current density on the rate of electrochemical oxidation was studied by performing the electrodegradation assays at three different current intensities, 4, 7 and $14 \mathrm{~A}$, at a flow rate of $360 \mathrm{~L} \mathrm{~h}^{-1}$, and using leachate volumes of 15,5 and $5 \mathrm{~L}$, respectively. Figure 1 presents 
the results of the normalized COD variation with time and with specific charge passed for these electrodegradation assays. Specific charge was calculated as $I t / V$, in $C L^{-1}$, where $I$ is the current intensity, in $\mathrm{A}, t$ is the time, in $\mathrm{s}$, and $V$ is the leachate volume, in $\mathrm{L}$.
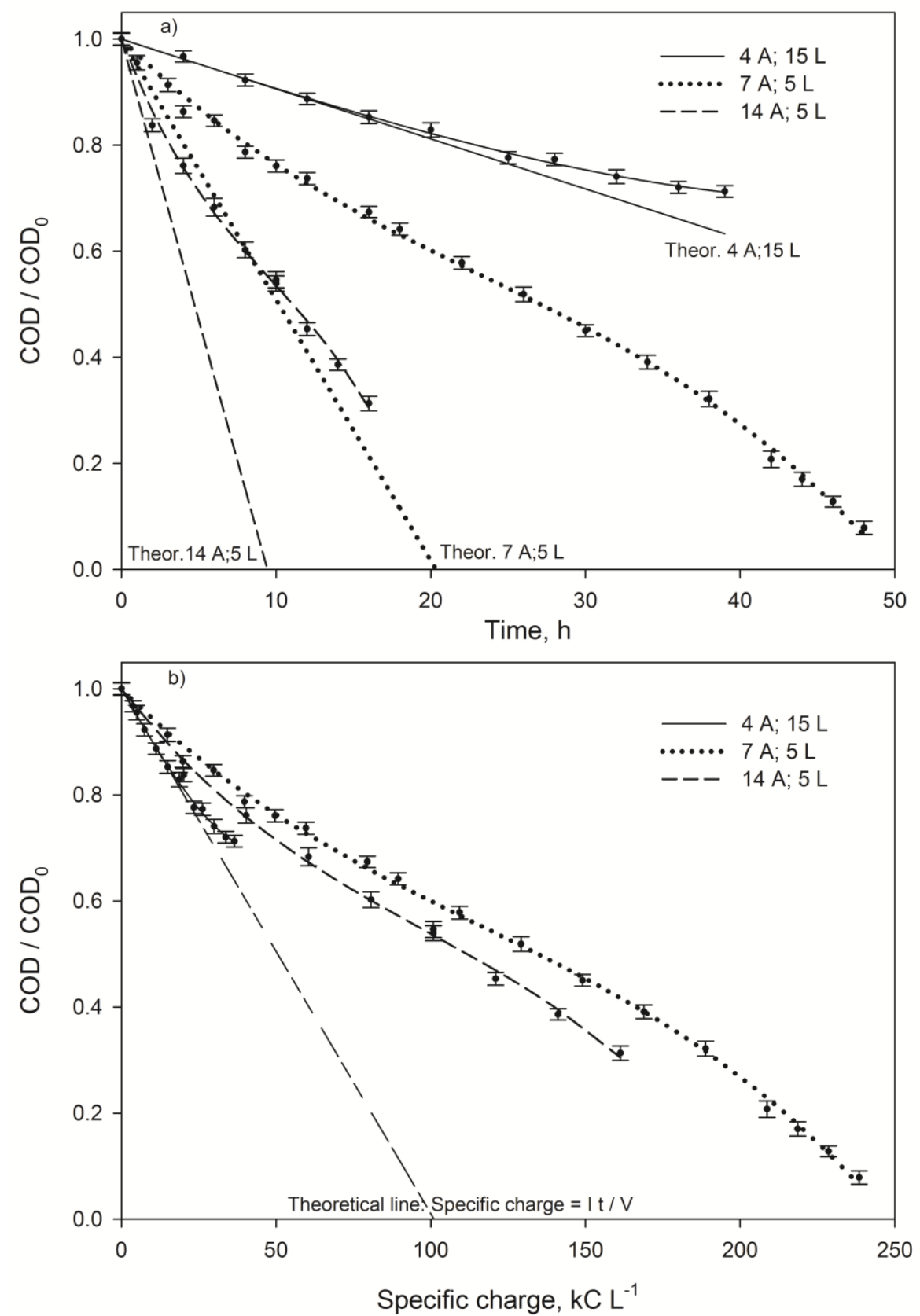

Figure 1. (a) Normalized COD variation with time for the electrodegradation assays performed at different current intensities, at a flow rate of $360 \mathrm{~L} \mathrm{~h}^{-1}$. (b) Normalized COD variation with specific charge for the electrodegradation assays performed at different current intensities, at a flow rate of $360 \mathrm{~L} \mathrm{~h}^{-1}$. Error bars refer to the standard deviation of the COD mean values.

It can be observed (Fig. 1a) that, for the assays performed with equal leachate volume COD removal rate increases with current density, which points to electrolysis operating under charge transfer control. In fact, for a single-compartment electrolytic reactor similar to the one used in this work, operating at flow rates of 200 and $600 \mathrm{~L} \mathrm{~h}^{-1}$, mass transport coefficients, $k_{\mathrm{m}}$, of $1.39 \times 10^{-5}$ and $1.5 \times 10^{-5} \mathrm{~m} \mathrm{~s}^{-1}$, for $200 \mathrm{~L} \mathrm{~h}^{-1}$, and $2.2 \times 10^{-5} \mathrm{~m} \mathrm{~s}^{-1}$, for $600 \mathrm{~L} \mathrm{~h}^{-1}$, are presented in literature [26-28]. With these $k_{m}$ values from literature, limiting currents between 10.4 and $16.5 \mathrm{~A}$ were obtained, 
showing that at least two of the assays presented in Fig. 1 started at current limited control conditions.

According to the model previously proposed in the literature for electrolysis under current limited control [29], i.e., at maximum current efficiency, the trend of COD during electrochemical oxidation can be predicted by Eq. (1), where $\mathrm{F}$ is the Faraday constant, $96485 \mathrm{C} \mathrm{mol}^{-1}$, and $V$ is the volume of the samples treated, in $\mathrm{m}^{3}$. Thus, theoretical slopes of COD vs. time, $1 / 4 F V$, can be calculated for each of the assayed current intensities.

$$
\operatorname{coD}(t)=\operatorname{COD}_{0}-\frac{1}{4 F V} t
$$

The comparison between these theoretical slopes and the experimental curves (Fig. 1a), for equal recirculation volume, shows that the discrepancy between experimental data and predicted slopes slightly decreases with current density. This can be explained if one assumes that the degradation process happens also by indirect oxidation. The increase in the leachate recirculation volume also seems to contribute to an increase in the efficiency of the process, due to the lower ratio electrode area/treated volume. In fact, when the volume is increased, keeping the same anodic area, the quantity of the compounds that are more easily degraded and that behave ideally augments. Thus, their concentration is kept higher for longer times when the recirculation volume is increased.

The effect of applied current on the trend of the COD with the specific charge consumed during the treatment (Fig. 1b) is less pronounced than the effect on the variation of COD vs. time. For equal leachate volume, an increase in current density leads to a more efficient use of the electric charge, since the experimental curve for $14 \mathrm{~A}$ is closer to the theoretical prediction. However, since higher current densities imply higher potentials, although the electric charge is more efficient the energetic consumption can be higher. Figure $1 \mathrm{~b}$ also shows that an increase in the leachate recirculation volume approaches the experimental results to the theoretical prediction.

To try to improve the current efficiency, assays were performed with successive decreases in current density, by steps, during the oxidation process, at different recirculation flow rates. In Figure 2 it can be observed the variation of normalized COD with specific charge for the assays run at constant (14 A) and variable current density ( $5 \mathrm{~h}$ at $14 \mathrm{~A}+5 \mathrm{~h}$ at $7 \mathrm{~A}+10 \mathrm{~h}$ at $4 \mathrm{~A}$ ), at a flow rate of $360 \mathrm{~L} \mathrm{~h}^{-1}$. COD removal seems to depend only on the charge passed. Variation of normalized COD with time (Fig. 2, inset) shows that during the first five hours, where the applied current density was equal, no difference can be seen in the COD removal rate. But, when the applied current density decreases, in the assays with steps, a decrease in the COD removal rate can be observed.

The influence of the recirculation flow rate in the electrochemical oxidation performance of the assays that were run with current density decreased by steps during the experiment was also studied. Figure 3 shows the normalized COD variation with the specific charge consumed for the assays performed with three or four current density steps at different recirculation flow rates: three steps, $5 \mathrm{~h}$ at $14 \mathrm{~A}+5 \mathrm{~h}$ at $7 \mathrm{~A}+10 \mathrm{~h}$ at $4 \mathrm{~A}$, flow rates of 160 and $360 \mathrm{~L} \mathrm{~h}^{-1}$, leachate volume $5 \mathrm{~L}$; four steps, $4 \mathrm{~h}$ at $14 \mathrm{~A}+4 \mathrm{~h}$ at $10.5 \mathrm{~A}+4 \mathrm{~h}$ at $7 \mathrm{~A}+4 \mathrm{~h}$ at $4 \mathrm{~A}$, flow rates of 100 and $950 \mathrm{~L} \mathrm{~h}^{-1}$, leachate volume $10 \mathrm{~L}$. 


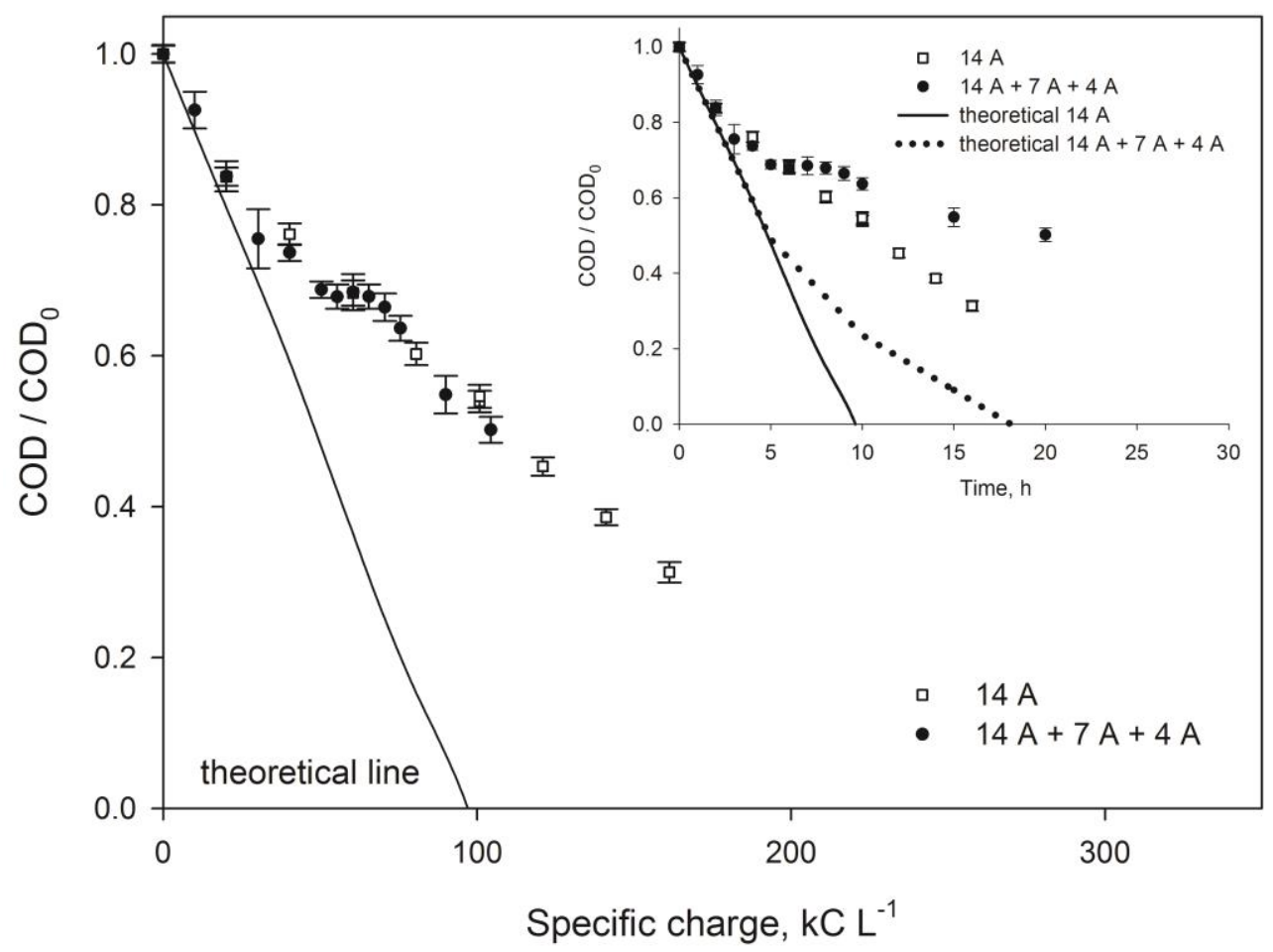

Figure 2. Normalized COD variation with specific charge passed and with time (inset) for the electrodegradation assays performed at constant and variable current intensity,_at a flow rate of $360 \mathrm{~L} \mathrm{~h}^{-1}$, with a leachate volume of $5 \mathrm{~L}$. Error bars refer to the standard deviation of the COD mean values.

The theoretical curves at these conditions are also presented. A slight variation in the trend of the COD depletion was observed, pointing to better removals at higher recirculation flow rates. The same behaviour is observed when normalized COD variation with electrolysis time is plotted (Fig. 3, insets). The discrepancy between experimental values and theoretical curves, after the first step of the assays, indicates a high loss in current efficiency that increases when current density is further decreased during the steps process.

Comparing the discrepancy between experimental values and theoretical curves for three and four steps, it can be concluded that charge efficiency is higher when four steps are applied, although this fact must be also related with the higher recirculation volume of leachate used in the four steps experiments.

Nitrogen removal was also assessed. In Figure 4 are plotted the normalized variation with time of ammonia nitrogen and of total nitrogen. Both parameters present similar behaviour of that described for COD in these assays, i.e., a decrease in the applied current density, in the steps assays, leads to a decrease in the nitrogen removal rates. It can be seen that, for the experiments performed at $14 \mathrm{~A}$, an increase in the removal rate is observed after eight hours assay. This fact is consistent with previous reports from other authors [23], which indicate that while BDD anodes promotes the generation of hydroxyl radicals, the high content of chloride induces the simultaneous formation of free chlorine, causing indirect oxidation of ammonium. In fact, this leachate presents high chloride concentration $\left(4.5 \mathrm{~g} \mathrm{~L}^{-1}\right)$, thus enhancing the chlorine evolution at lower COD concentrations, justifying the increase in the nitrogen removal rate when COD levels are lower. In contrast to what was observed with COD removal, nitrogen removal is higher when the recirculation flow rate is lower. In fact, at higher flowrates COD oxidation is favoured, chlorine 
evolution, that is a competitive reaction, is delayed as a consequence and thus it influences and slows down the rate of ammonium removal.

In order to analyse the energy consumption, the specific energy consumptions, $E_{\mathrm{sp}}$, in $\mathrm{W}$ h/g COD removed were calculated, by means of Eq. (2):

$$
E_{s p}=\frac{U I \Delta t}{V \Delta C O D}
$$

where $U$ is the cell voltage, in $V$, resulting from the applied current intensity $I$, in $A, \Delta t$ is the duration of the electrolysis, in $\mathrm{h}, V$ is in $\mathrm{m}^{3}$ and $\Delta C O D$ is the removed COD, in $\mathrm{g} \mathrm{m}^{-3}$, during $\Delta t$.
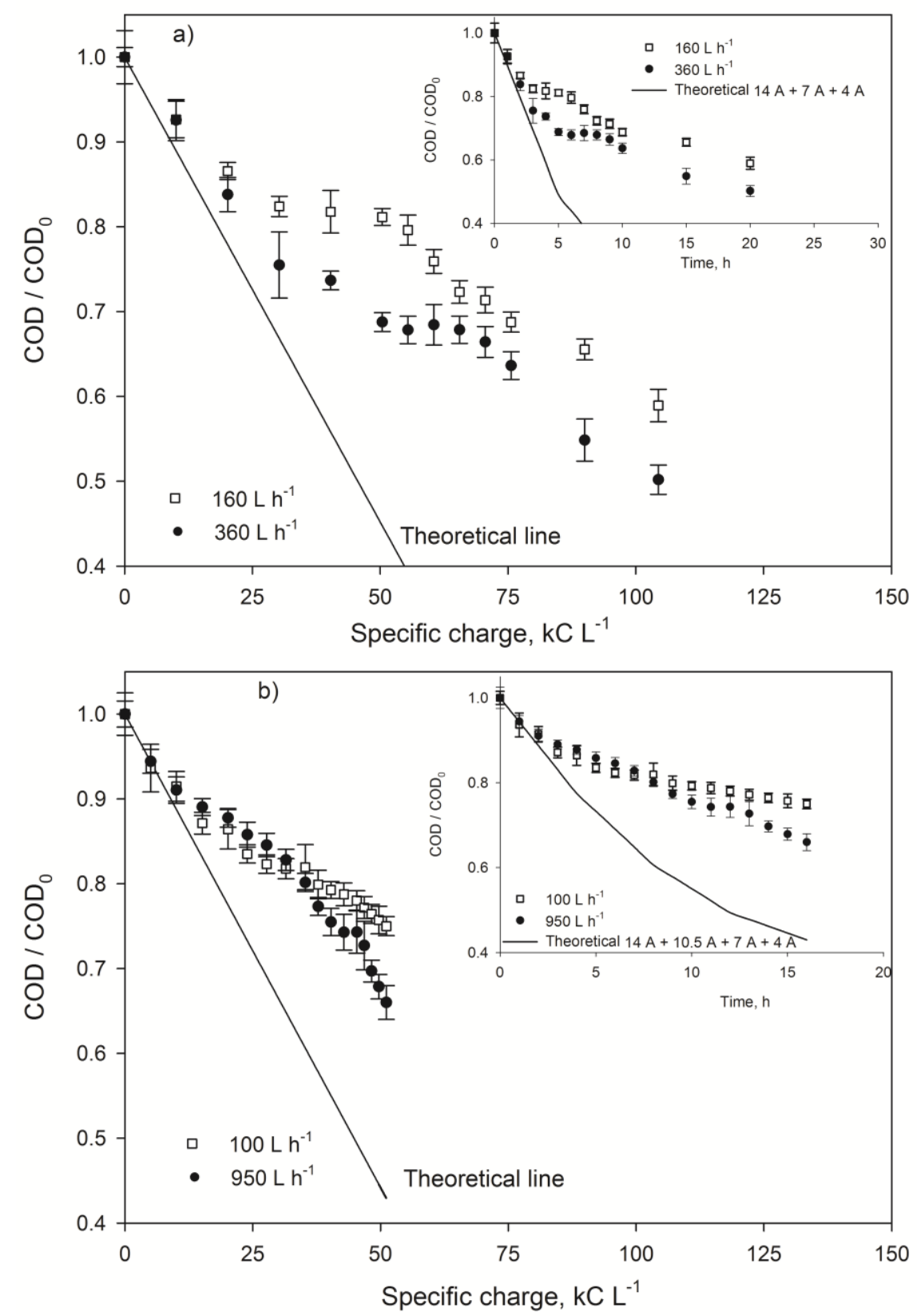

Figure 3. Normalized COD variation with specific charge and with time (inset) for electrodegradation assays performed with (a) three current density steps, with a leachate volume of $5 \mathrm{~L}$ and with (b) four current density steps, with a leachate volume of $10 \mathrm{~L}$. Error bars refer to the standard deviation of COD mean values. 

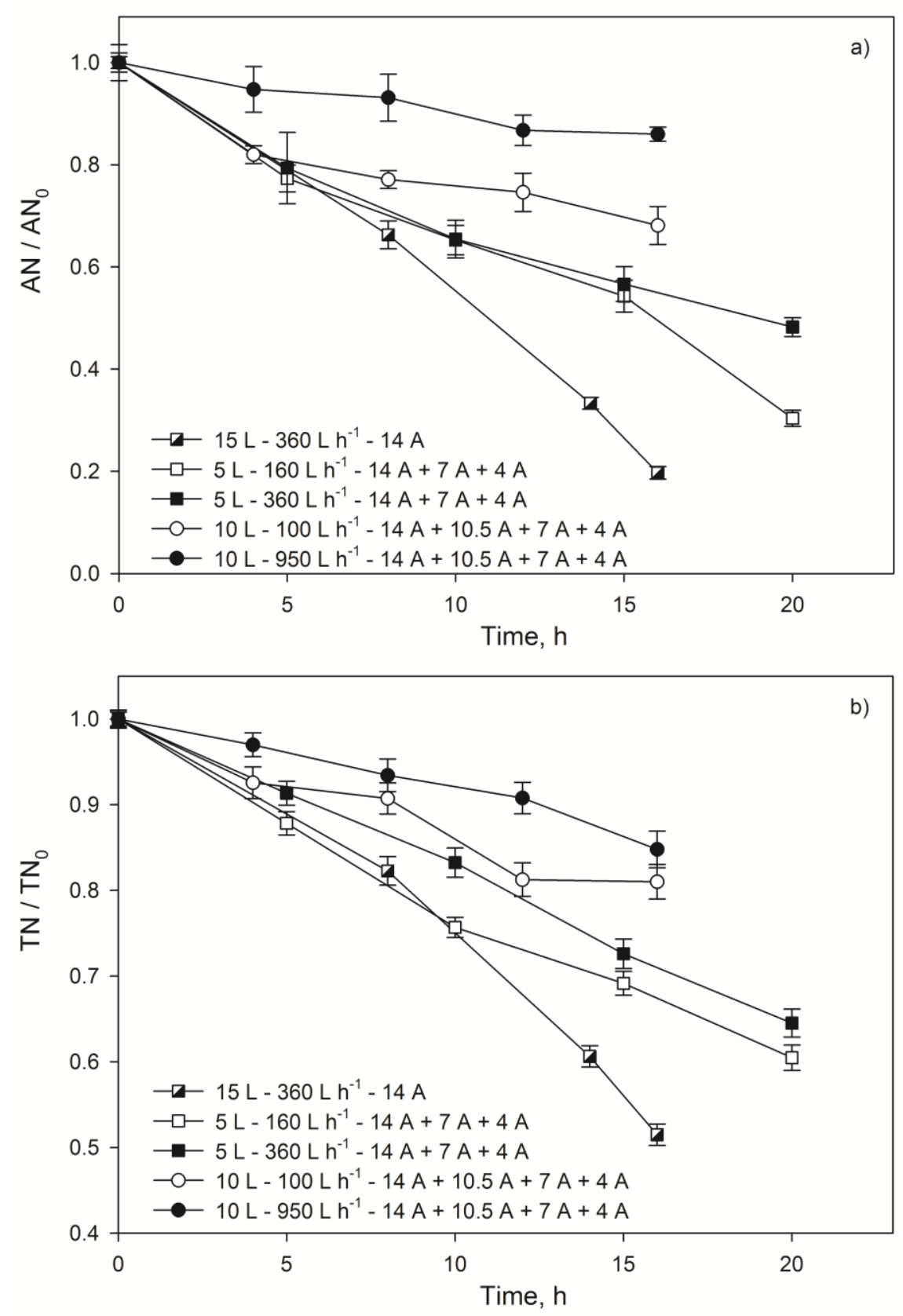

Figure 4. (a) Normalized ammonia nitrogen variation with time for the electrodegradation assays performed at constant current density and at three and four current density steps.

(b) Normalized total nitrogen variation with time for the electrodegradation assays performed at constant current density and at three and four current density steps.

Figure 5 reports the specific energy consumption as a function of the time for the different assays performed. The specific energy consumption seems to increase with current density (Fig. 5a), which is a consequence of the increase in potential when the current density is increased. When constant current density was imposed (Fig. 5a), there is an increase in the energy consumption during the first part of the assay, followed by a decrease. This behavior must be due to the different types of compounds that are present and that are not degraded simultaneously, being first degraded those that are present in higher concentration and, among them, those who have higher diffusion coefficients. The introduction of steps, although leads to a overall decrease in the energetic consumption, did not present the expected results in terms of specific energy consumption, since it leads to more irregular consumptions rather than lower consumptions 
(Fig. 5b). For these assays, an increase in the recirculation flow rate seems to slightly decrease the $E_{s p}$ (Fig. $5 c$ and $5 d$ ). On the other hand, the increase in the leachate volume being recirculated really decreases the specific energy consumption, since the values in the yy' axis are much lower in Fig. $5 d(10 \mathrm{~L})$ than in Fig. $5 c(5 \mathrm{~L})$.
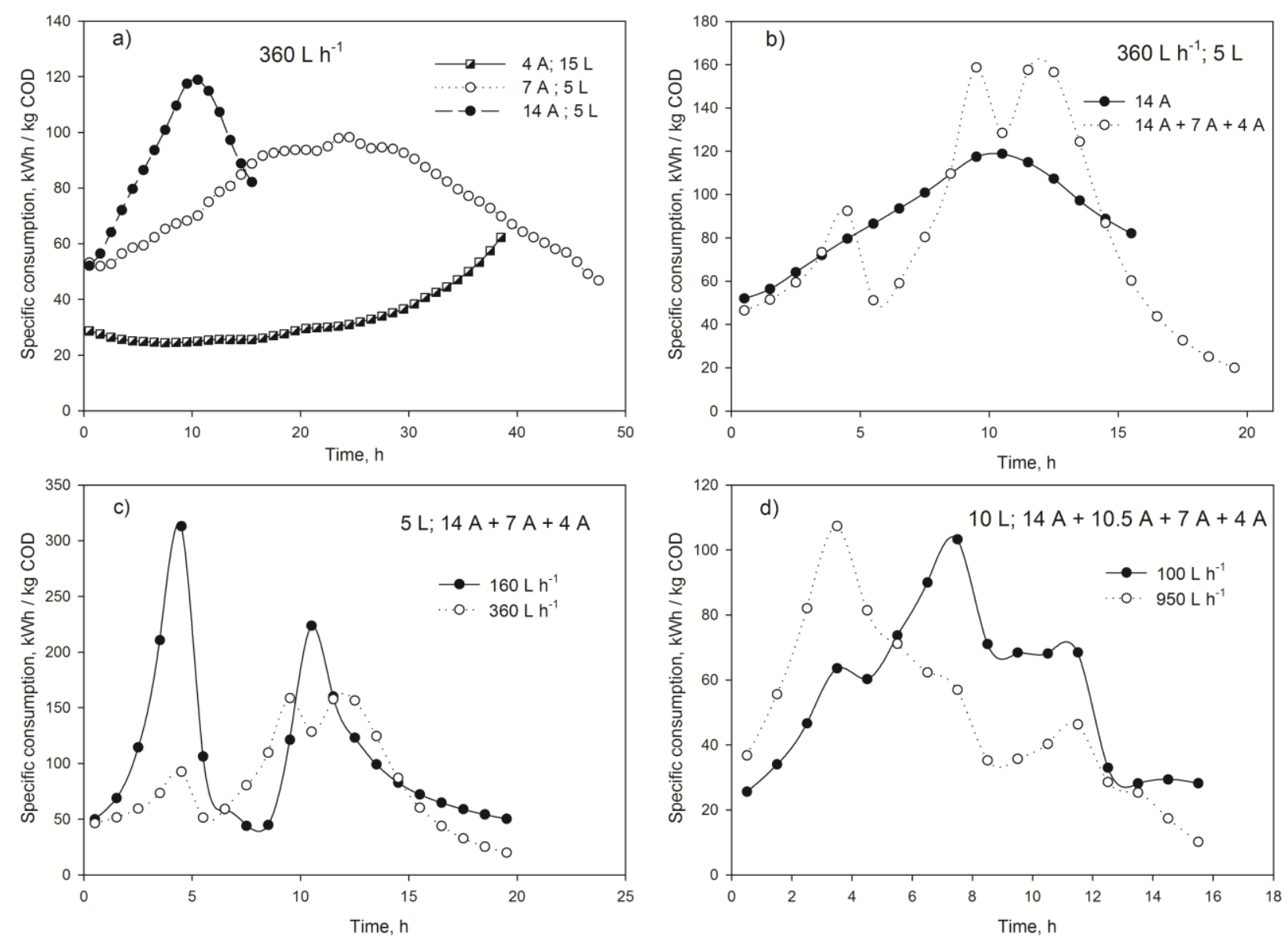

Figure 5. Evolution of specific energy consumption with time for (a) electrodegradation assays performed at different current densities, at a flow rate of $360 \mathrm{~L} \mathrm{~h}^{-1}$ (b) electrodegradation assays performed at constant and variable current density, at a flow rate of $360 \mathrm{~L} \mathrm{~h}^{-1}$ (c) electrodegradation assays performed with three current density steps at different recirculation flow rates, with a leachate volume of $5 \mathrm{~L}(\mathrm{~d})$ electrodegradation assays performed with four current density steps at different recirculation flow rates, with a leachate volume of $10 \mathrm{~L}$.

The removals in COD, DOC, TN, TKN and AN for all assays performed with current density decreased by steps, as well as the medium specific energy consumption, are presented in Table 2. This table includes also the results obtained in the assay performed at constant current intensity of $14 \mathrm{~A}$ and $360 \mathrm{~L} \mathrm{~h}^{-1}$ recirculation flow rate, in order to allow comparison between assays performed with and without reduction in the current intensity during the assay. The apparent discrepancy between absolute and percentage values presented in Table 2 is due to the variation of the experimental determinations of those parameters for the different assays, due to the complexity and heterogeneity of the leachate suspension. Data reported confirm the previous analysis, showing that for both multiple step designs, with 3 or 4 current density steps, and for a wide range of recirculation flow rate, from 100 to $950 \mathrm{~L} \mathrm{~h}^{-1}$, an increase in the recirculation flow rate increases COD removal rate and decreases nitrogen removal rate (TN, TKN and AN). Also, it can be seen that DOC removals are always lower than COD removals and these differences increase with flow rate, indicating that a decrease in the flow rate increases the mineralization index. Regarding the energy 
consumption, an increase in the recirculation flow rate leads to a decrease in the medium energy consumption, mainly because COD removal rate increases with recirculation flow rate.

Table 2. COD, DOC, TN, TKN and AN removals and medium specific energy consumption for assays performed with one, three and four current density steps at different recirculation flow rates.

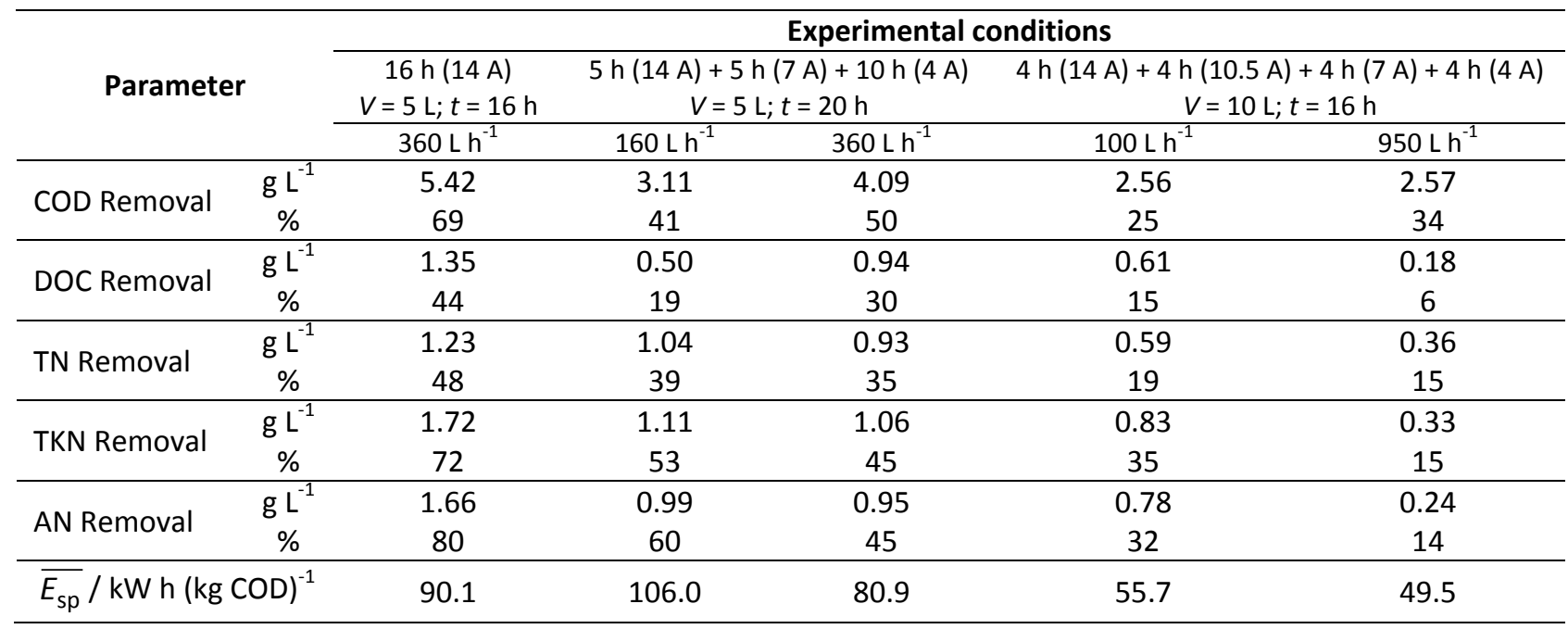

\section{Conclusions}

The anodic oxidation was used to treat leachate from an intermunicipal sanitary landfill and the following conclusions can be drawn:

- Organic load removal rate increases with applied current density. This happens mainly because, due to the high organic load content, the electrochemical processes are under current control most of the assay period.

- An increase in the recirculation flow rate leads to an increase in the organic load removal rate. However, it decreases the nitrogen removal.

- By reducing the current density along the anodic oxidation process it is possible to reduce energetic costs. Similar results can be obtained by increasing the recirculation flow rate.

- DOC removals are always lower than COD removals and these differences increase with flow rate. Thus, a decrease in flow rate seems to increase the mineralization index.

Thus, although huge variations can be found in the composition of leachates from sanitary landfills, the anodic oxidation, performed with a BDD anode, can be an alternative/complement to treat this kind of wastewaters. Also, the variation found in the medium specific energy consumption shows that it is possible to optimize the process in order to reduce energy costs.

Acknowledgements: Financial support from FEDER, Programa Operacional Factores de Competitividade - COMPETE, and FCT, for the projects PTDC/AAC- AMB/103112/2008 and PEstOE/CTM/UI0195/2011 of the MT\&P Unit and for A. Fernandes grant to SFRH/BD/81368/2011.

\section{References}

[1] T. Eggen, M. Moeder, A. Arukwe, Science of The Total Environment 408 (2010) 5147-5157

[2] C.B. Öman, C. Junestedt, Waste Management 28 (2008) 1876-1891

[3] A.A. Abbas, G. Jingsong, L.Z. Ping, P.Y. Ya, W.S. Al-Rebaki, Journal of Applied Sciences Research 5 (2009) 534-545

[4] G. Chen, Separation and Purification Technology 38 (2004) 11-41

[5] C.A. Martínez-Huitle, S. Ferro, Chemical Society Reviews 35 (2006) 1324-1340 
[6] C. Comninellis, A. Kapalka, S. Malato, S.A. Parsons, I. Poulios, D. Mantzavinos, Journal of Chemical Technology \& Biotechnology 83 (2008) 769-776

[7] A. Anglada, A. Urtiaga, I. Ortiz, Journal of Chemical Technology \& Biotechnology 84 (2009) 1747-1755

[8] C.A. Martínez-Huitle, E. Brillas, Applied Catalysis B: Environmental 87 (2009) 105-114

[9] M. Panizza, G. Cerisola, Chemical Reviews 109 (2009) 6541-6569

[10] D. Ghernaout, M.W. Naceura, A. Aouabeda, Desalination 270 (2011) 9-22

[11] M. Panizza, G. Cerisola, Electrochimica Acta 51 (2005) 191-199

[12] J.H.T. Luong, K.B. Male, J.D. Glennon, Analyst 134 (2009) 1965-1979

[13] M. Panizza, M. Delucchi, I. Sirés, Journal of Applied Electrochemistry 40 (2010) 1721-1727

[14] A. Cabeza, A. Urtiaga, M.J. Rivero, I. Ortiz, Journal of Hazardous Materials 144 (2007) 715719

[15] A. Cabeza, A. Urtiaga, I. Ortiz, Industrial \& Engineering Chemistry Research 46 (2007) 14391446

[16] Y. Deng, J.D. Englehardt, Waste Management 27 (2007) 380-388

[17] A. Anglada, A. Urtiaga, I. Ortiz, Environmental Science \& Technology 43 (2009) 2035-2040

[18] A. Urtiaga, A. Rueda, Á. Anglada, I. Ortiz, Journal of Hazardous Materials 166 (2009) 15301534

[19] G. Zhao, Y. Pang, L. Liu, J. Gao, B. Lv, Journal of Hazardous Materials 179 (2010) 1078-1083

[20] A. Anglada, A.M. Urtiaga, I. Ortiz, Journal of Hazardous Materials 181 (2010) 729-735

[21] A. Anglada, A. Urtiaga, I. Ortiz, D. Mantzavinos, E. Diamadopoulos, Water Research 45 (2011) 828-838

[22] A. Fernandes, M.J. Pacheco, L. Ciríaco, A. Lopes, Journal of Hazardous Materials 199-200 (2012) 82-87

[23] A. Urtiaga, I. Ortiz, A. Anglada, D. Mantzavinos, E. Diamadopoulos, Journal of Applied Electrochemistry 42 (2012) 779-786

[24] G. Pérez, J. Saiz, R. Ibañez, A.M. Urtiaga, I. Ortiz, Water Research 46 (2012) 2579-2590

[25] A. Eaton, L. Clesceri, E. Rice, A. Greenberg, M.A. Franson, Standard Methods for Examination of Water and Wastewater, twenty-first ed., American Public Health Association, Washington, DC, 2005

[26] R. Bellagamba, P.A. Michaud, Ch. Comninellis, N. Vatistas, Electrochemistry Communications 4 (2002) 171-176

[27] L. Gherardini, P.A. Michaud, M. Panizza, Ch. Comninellis, N. Vatistas, Journal of the Electrochemical Society 148 (2001) D78-D82

[28] E. Chatzisymeon, N. Xekoukoulotakis, E. Diamadopoulos, A. Katsaounis, D. Mantzavinos, Water Research 43 (2009) 3999-4009

[29] M. Pannizza, P.A. Michaud, G. Cerisola, C. Comninellis, Journal of Electroanalytical Chemistry 507 (2001) 206-214

(C) 2013 by the authors; licensee IAPC, Zagreb, Croatia. This article is an open-access article distributed under the terms and conditions of the Creative Commons Attribution license (http://creativecommons.org/licenses/by/3.0/) 